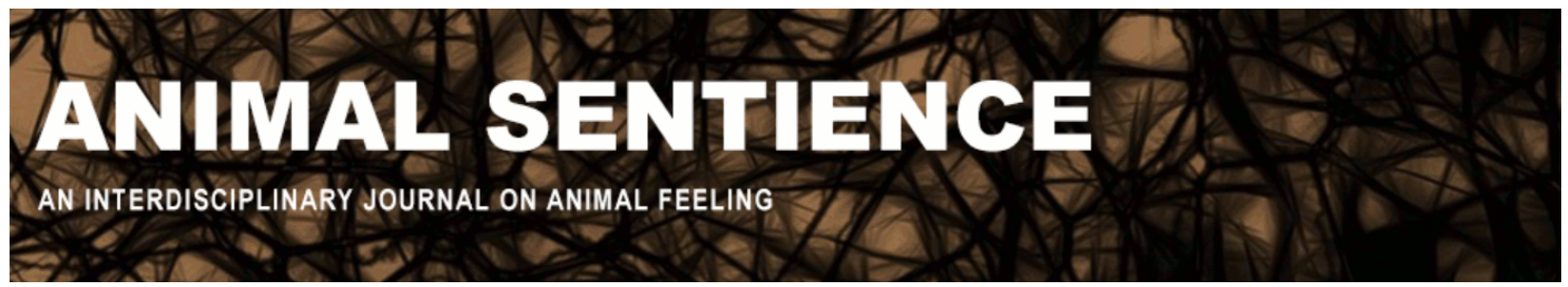

Brodbeck, David R.; Brodbeck, Madeleine I. R.; and Rosso, Keeghan (2019)

Domestication and cognitive complexity. Animal Sentience 25(32)

DOI: $10.51291 / 2377-7478.1478$

Date of submission: 2019-06-05

Date of acceptance: 2019-06-10

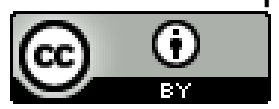

This article has appeared in the journal Animal

Sentience, a peer-reviewed journal on animal

cognition and feeling. It has been made open access,

free for all, by WellBeing International and deposited

in the WBI Studies Repository. For more information,

please contact

wbisr-info@wellbeingintl.org.

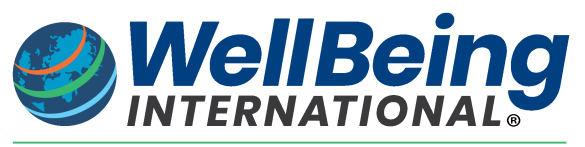

SOLUTIONS FOR PEOPLE, ANIMALS AND ENVIRONMENT 


\title{
Domestication and cognitive complexity
}

Commentary on Marino \& Merskin on Sheep Complexity

\author{
David R. Brodbeck \\ Department of Psychology \\ Algoma University \\ Madeleine I. R. Brodbeck \\ Department of Psychology \\ University of Western Ontario \\ Keeghan Rosso \\ Department of Psychology \\ Algoma University
}

\begin{abstract}
Marino and Merskin (2019) list a number of tasks that sheep can perform well. As comparative psychologists, we are not surprised by these results. Indeed, many domesticated animal species show similar abilities.
\end{abstract}

David R. Brodbeck is an associate professor of psychology at Algoma University in Sault Ste. Marie, ON, Canada. His work focusses on the evolution of cognition, especially spatial memory. Brodbeck also hosts the animal cognition podcast Spit and Twitches. Website

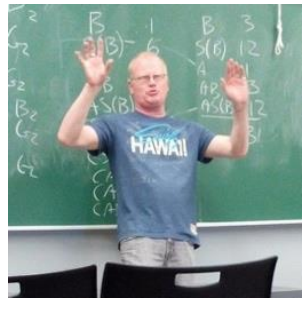

Madeleine I. R. Brodbeck is a PhD student in psychology at the University of Western Ontario in London, ON, Canada. Her work focuses on the role of Cluster $\mathrm{N}$ in songbird migration.

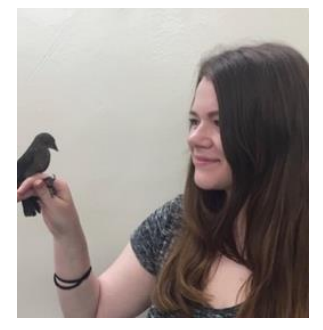

Keeghan Rosso is an undergraduate psychology student at Algoma University in Sault Ste. Marie, ON, Canada. He is interested in animal cognition and behavior. 
Domestic animals such as livestock and companion animals were selectively bred by humans. Domestication has occurred both with direct intent by humans (e.g., livestock) but also indirectly (domestic dog, Larson \& Bradley, 2014). These artificial selection pressures produced animals that humans wanted as work animals (e.g., horses) pets (e.g., dogs and cats) or livestock (e.g., sheep, pigs, cows, chickens etc.). Considering humans were selecting for particular behavioral traits, say docility or friendliness, some may consider these animals less intelligent than their wild relatives. Such a view is an almost textbook example of anthropomorphizing. Indeed, shy humans are perceived as being less intelligent than their outgoing peers even though there is no evidence that shyness correlates with IQ (Paulhus \& Morgan, 1997). It should also be noted that intelligence, that is, problem-solving ability, in animals must be related to the niches that they evolved in, not to some human intuition of what intelligence is (Shettleworth, 1993, 2010; Kamil, 1987).

Domestication, then, need not mean unintelligent, or lacking in cognitive complexity. Domesticated animals have been studied extensively by comparative psychologists. For example, Thorndike (1911) developed his puzzle boxes to test domestic cats. This is the case even if one excludes rats and pigeons, which, could be argued, are domesticated animals. Indeed, Thorndike (1911) developed his puzzle boxes to test problem solving in domestic cats. At the most recent meeting of the Comparative Cognition Society (2019), of the 155 presentations, 26 focused on cognition in dogs, cats, horses and pigs. Indeed, an entire paper session was devoted to canine cognition (Comparative Cognition Society, 2019).

Marino and Merskin (2019) present a long list of tasks that sheep have been tested on. We conducted a quick search and found that these results are mirrored in other domesticated species (Table 1).

Table 1: Selected Results from Cursory Literature Search on Domestic Animals' Cognition

\begin{tabular}{|c|c|c|c|}
\hline $\begin{array}{l}\text { Task in Section } 5 \text { of Marino \& } \\
\text { Merskin (2019) }\end{array}$ & $\begin{array}{l}\text { Domestic } \\
\text { Animal }\end{array}$ & Method \& Result & Reference \\
\hline Executive function & Dog & Self-control & Miller et al., 2010 \\
\hline Visual discrimination & Horse & $\begin{array}{l}\text { Difference in visual discrimination } \\
\text { dependent on height }\end{array}$ & $\begin{array}{l}\text { Hall, Cassaday \& } \\
\text { Derrington, } 2003\end{array}$ \\
\hline Reversal learning & Chick & Reversal learning on a T maze & Warren et al., 1960 \\
\hline Attentional set shifting & Dog & Attentional set shift on a maze & Bondi et al., 2015 \\
\hline "Other" spatial memory & $\begin{array}{l}\text { Cow } \\
\text { Pig } \\
\text { Horse } \\
\text { Horse } \\
\text { Dog }\end{array}$ & $\begin{array}{l}\text { Radial maze } \\
\text { Open field } \\
\text { Y maze not successful } \\
\text { Y maze successful } \\
\text { Radial maze }\end{array}$ & $\begin{array}{l}\text { Bailey et al., } 1989 \\
\text { Mendl et al., } 1997 \\
\text { McLean, } 2004 \\
\text { Baragli et al., } 2011 \\
\text { MacPherson \& } \\
\text { Roberts, } 2010\end{array}$ \\
\hline Learn tasks in two trials (or less) & Chicken & Taste aversion & Atkinson et al., 2003 \\
\hline
\end{tabular}




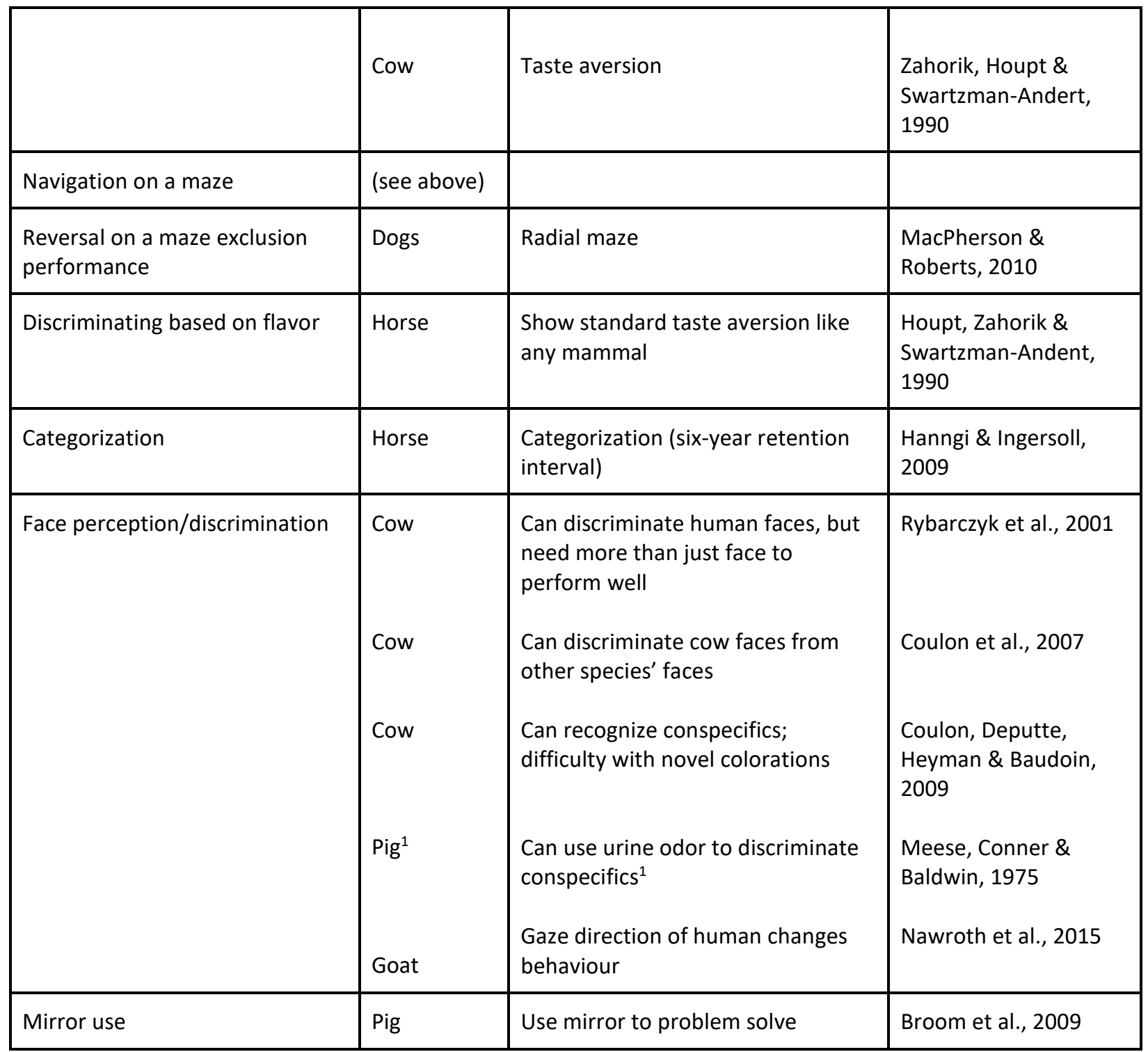

${ }^{1}$ This example is included even though the pigs in question were not discriminating faces. There are many ways to discriminate between conspecifics; concentrating on faces is simply anthropomorphism.

As this table makes clear, the results reported by Marino and Merskin (2019) for sheep are not unique. Examples for other domesticated animals were easily found.

While sheep may indeed be cognitively complex animals with rich mental lives, that is true of other domesticated animals, and surely true of wild animals, both vertebrate and invertebrate (see Shettleworth, 2010, for an excellent review). 


\section{References}

Atkinson, R., Bevilaqua, L.R.M., Rostas, J.A.P. \& Hunter, M. (2003). Discriminative taste aversion learning: A learning task for older chicken. Neurobiology of Learning and Memory, 79(1), 25-31.

Bailey, D.W., Rittenhouse, L.R., Hart, R.H. \& Richards, R.W. (1989). Characteristics of spatial memory in cattle. Applied Animal Behaviour Science, 23(4), 331-340.

Baragli, P., Vitale, V., Paoletti, E., Mengoli, M. \& Sigheiri, C. (2011). Encoding the object position for assessment of short term spatial memory in horses (Equus caballus). International Journal of Comparative Psychology, 24(3), 284-291.

Bondi, C.O., Cheng, J.P., Tennant, H.M., Monaco, C.M. \& Kline, A.E. Old dog, new tricks: The attentional set-shifting test as a novel cognitive behavioral task after controlled cortical impact injury. Journal of Neurotrauma, 31(10), 926-937.

Broom, D.M., Sena, H. \& Moynihan, K.L. (2009). Pigs learn what a mirror image represents and use it to obtain information. Animal Behaviour, 78(1), 1037-1041.

Comparative Cognition Society. (2019). Final program, conference on comparative cognition. Melbourne, $\mathrm{FL}$, April.

Coulon, M., Deputte, B.L., Heyman, Y. \& Baudoin, C. (2009). Individual recognition in domestic cattle (Bas taurus): Evidence from 2D-images of heads from different breeds. PLoS ONE, 4(2), e4441.

Coulon, M., Deputte, B.L., Heyman, Y., Delatouche, L., Richard, C. \& Baudoin, C. (2007). Visual discrimination by heifers (Bos taurus) of their own species. Journal of Comparative Psychology, 121(2), 198-204.

Hall, C.A., Cassaday, H.J. \& Derrington, A.M. (2003). The effect of stimulus height on visual discrimination in horses. Journal of Animal Science, 81(7), 1715-1720.

Hanngi, E.B. \& Ingersoll, J.F. (200). Long-term memory for categories and concepts in horses (Equus caballus). Animal Cognition, 12(3), 451-462.

Houpt, K.A., Zahorik, D.M. \& Swartzman-Andert, J. (1990). Taste aversion learning in horses. Journal of Animal Science, 68(8), 2340-2344.

Kamil, A.C. (1987). A synthetic approach to the study of animal intelligence. Nebraska Symposium on Motivation, 35, 257-308.

Larson, G. \& Bradley, D.G. (2014). How much is that in dog years? The advent of canine population genomics. PLoS Genetics, 10(1), e1004093.

MacPherson, K. \& Roberts, W.A. (2010). Spatial memory in dogs (Canis familiaris) on a radial maze. Journal of Comparative Psychology, 124(1), 47-56. 
Marino, L. \& Merskin, D. (2019). Intelligence, complexity and individuality in sheep. Animal Sentience 25(1).

McLean, A.N. (2004). Short term spatial memory in the domestic horse. Applied Animal Behaviour Science, 85(1), 93-105.

Meese, G.B., Conner, D.J. \& Baldwin, B.A. (1975). Ability of the pig to distinguish conspecific urine samples using olfaction. Physiology and Behavior, 35(1), 120-125.

Mendl, M., Laughlin, K. \& Hitchcock, D. (1997). Pigs in space: Spatial memory and its susceptibility to interference. Animal Behaviour, 54(6), 1491-1508.

Miller, H.C., Pattison, K.F., DeWall, C.N., Rayburn-Reeves, R. \& Zentall, T.R. (2010). Self-control without a self? Common self-control processes in humans and dogs. Psychological Science, 21(4), 534-538.

Nawroth, C., von Borrell, E. \& Langbein, J. (2015). 'Goats that stare at men': Dwarf goats alter their behavior in response to human head orientation, but do not spontaneously use head direction as a cue in a food-related context. Animal Cognition, 18(1), 65-73.

Paulhus, D.H. \& Morgan, K.L. (1997). Perceptions of intelligence in learderless groups: The dynamic effects of shyness and acquaintance. Journal of Personality and Social Psychology, 72(3), 581-591.

Rybarczyk, P., Koba, Y., Rushen, J., Tanida, H. \& de Passillé, A.M. (2001). Can cows discriminate people by their faces? Applied Animal Behaviour Science, 74(3), 175-189.

Shettleworth, S.J. (1993). Where is the comparison in comparative cognition: Alternative research programs. Psychological Science, 4(3), 179-184.

Shettleworth, S.J. (2010). Cognition, evolution and behavior ( $2^{\text {nd }}$ Ed.). Oxford.

Thorndike, E.L. (1911). Animal intelligence. MacMillan.

Warren, J.M., Brookshire, K.H., Ball, G.G. \& Reynolds, D.V. (1960). Reversal learning by white leghorn chicks. Journal of Comparative and Physiological Psychology, 53(4), 371-375.

Zahorik, D.M., Houpt, K.A. \& Swartzman-Andert, J. (1990). Taste aversion learning in three species of ruminants. Applied Animal Behaviour Science, 26(1), 27-39. 